\title{
Tembikar Song Tritis: Suatu Bukti Permukiman Berkelanjutan
}

\section{Goenadi Nitihaminoto}

Keywords: pottery, prehistory, cave, settlement, technology

\section{How to Cite:}

Nitihaminoto, G. (2006). Tembikar Song Tritis: Suatu Bukti Permukiman Berkelanjutan. Berkala Arkeologi, 26(1), 12-20. https://doi.org/10.30883/jba.v26i1.921

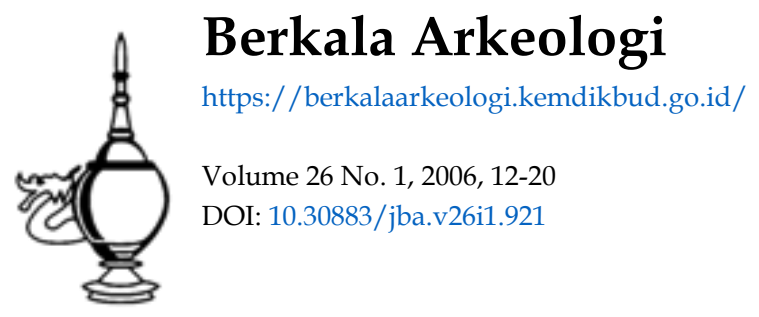

\section{(c) (i)(2)}

This work is licensed under a Creative Commons Attribution-NonCommercial-ShareAlike 4.0 International License. 


\section{TEMBIKAR SONG TRITIS: \\ SUATU BUKTI PERMUKIMAN BERKELANJUTAN \\ Goenadi Nitihaminoto}

\section{Pendahuluan}

Makalah ini disusun berdasarkan hasil penelitian di Situs Song Tritis pada tahun 2002. Penelitian sesudah tahun 2002 hasilnya relatif sama baik jenis dan kuantitasnya. Perbedaan mungkin terjadi pada kondisi lapisan tanah dan pertanggalan absolut. Jumlah lapisan tanah akan bertambah bila ekskaasi dilakukan semakin dalam dan pertanggalan absolut akan bertambah tua yang menandai aktifitas kehidupan di Situs Song Tritis yang paling tua, sesuai dengan kemampuan ekskavasi. Dengan demikian, pertanggalan tertua dalam tulisan ini belum dapat mewakili masa kehidupan tertua di Situs Song Tritis karena diduga akan ditemukan pertanggalan yang lebih tua yang diperoleh dalam penelitian-penelitian mendatang.

Song, merupakan sebutan penduduk setempat untuk menamakan sebuah cenuk atau gua. Song Tritis merupakan salah satu gua (rockshelter) yang terdapat di wilayah Kabupaten Gunung Kidul, Yogyakarta. Gua ceruk itu terletak di Dusun Semampir, Desa Semugih, Kecamatan Rongkop. Song Tritis terletak sekitar 9 km di sebelah utara pantai Samudera Hindia atau sekitar $2 \mathrm{~km}$ di sebelah utara Rongkop, dan sekitar 150 meter di sebelah timur jalan raya yang menghubungkan antara Baran dan Sadeng. Song Tritis dapat ditemukan berjarak $2 \mathrm{~km}$ di selatan Baran. Secara astronomis, Song Tritis terletak antara $8^{\circ} 6^{\prime} 2^{\prime \prime}$ Lintang Selatan dan $3^{\circ} 56^{\prime} 24^{\prime \prime}$ Bujur Timur. Song Tritis menghadap ke barat daya terletak pada ketinggian 345,80 meter di atas permukaan air laut. Lebar pintu masuk 30 meter, tinggi 7 meter, panjang dataran ceruk 50 meter, lebar 20 meter, dan tinggi langitlangit 9 meter. Ukuran itu menggambarkan bahwa Song Tritis merupakan ceruk yang berukuran besar (Widianto, 2000).

Terima kasih kepada Dr. Harry Widianto yang telah memberi kemudahan untuk penggunaan data hasil penelitian Situs Song Tritis, sehingga tulisan ini dapat diselesaikan. 
Temuan Situs Song Tritis sangat kompleks yang antara lain terdiri atas batu inti, serpih, bilah, serut, kapak penetak, chopper, serut dari cangkang molusca, lancipan tulang, pecahan tembikar, dan uang voc. Alat-alat batu ditemukan dari kedalaman paling dalam hingga lapisan tanah paling atas. Sementara itu, temuan pecahan tembikar terdapat antara spit (1) hingga spit (7), sedangkan uang voc terletak pada spit paling atas (1). Temuan nonartefak terdiri atas tulang dan rangka manusia, cangkang molusca, dan yang paling banyak adalah tulang Macacaca $s p$. Temuantemuan itu berhubungan sangat erat dengan lapisan tanah. Lapisan tanah yang diambil sebagai sample berasal dari kotak M15 yang diekskavasi hingga kedalaman $290 \mathrm{~cm}$ (penelitian tahun 2002). Dari salah satu dindingnya dapat dilihat empat lapisan tanah, yaitu lapisan tanah atas (top soil), lapisan tanah pertama, lapisan tanah kedua, dan lapisan tanah ketiga. Batuan top soil berupa lempung lanauan, warna abu-abu gelap, lepas, mengandung pecahan batu kristalin.

Temuan yang terdapat di dalam top soil terdiri atas artefak batu, pecahan - tembikar, cangkang moluska, dan tulang mikro fauna. Lapisan tanah pertama berupa lempung coklat kemerahan, sedikit pasiran, kompak, mengandung pecahan batu gamping kristalin, artefak batu, pecahan tembikar, dan tulang vertebrata. Lapisan tanah kedua berupa lempung lanauan bercampur dengan abu sisa pembakaran warna coklat keabuan, indurasi sangat rendah dan lepas. Temuan yang terdapat di dalamnya berupa sisa fauna (vertebrata dan molusca) dalam kuantitas melimpah, rangka manusia, alat-alat batu, dan alat-alat tulang. Lapisan tanah ketiga berupa lempung lanauan berwarna coklat keabuan, indurasi sangat rendah dan lepas. Lapisan tanah itu mengandung temuan sisa fauna (vertebrata dan molusea) dalam kuantitas melimpah, alat-alat batu, dan alat-alat tulang.

Lapisan tanah ketiga hingga lapisan tanah pertama telah diketahui pertanggalannya yang dilakukan oleh Laboratorium Pertanggalan Radio-carbon Pusat Pengembangan dan Penelitian Geologi Bandung dengan menggunakan media tulang binatang pada masing-masing lapisan tanah tersebut. Hasil analisis $\mathrm{C}^{14}$ pada lapisan tanah ketiga kedalaman $290 \mathrm{~cm}$ adalah 8000 tahun yang lampau, kemudian sampel diambil dari kedalaman $180 \mathrm{~cm}-90 \mathrm{~cm}$ berasal dari 6000 tahun yang lampau, dan lapisan tanah kedua sampelnya diambil dari kedalaman 
antara $90 \mathrm{~cm}-80 \mathrm{~cm}$ berasal dari kehidupan 3000 tahun lampau, sedangkan lapisan tanah pertama yang sampelnya diambil dari kotak J13 dari kedalaman 50 cm di bawah permukaan tanah berasal dari $1110 \pm$ atau sekitar 1000 tahun yang lalu. Data pertanggalan tersebut memberikan gambaran bahwa kehidupan suatu komunitas gua di Situs Song Tritis berlangsung hingga abad ke-11 M, dan berdasarkan temuan uang voc berlanjut hingga abad ke-17 $\mathrm{M}$, merupakan komunitas yang hidup berkelanjutan yang terjadi pada tempat yang sama.

Keberadaan rangka manusia yang ditemukan pada permukaan lapisan tanah kedua cukup penting, karena tidak ditemukan pada tahap penelitian sebelumnya. Rangka manusia itu ditemukan di kotak L17-18 pada penelitian tahun 2002, pada kedalaman $30 \mathrm{~cm}$ di bawah permukaan tanah. Kepala (cranium) tidak ditemukan, tetapi rahang bawah (mandibula) ditemukan di utara. Hal itu menunjukkan bahwa penguburan yang pernah dilakukan dengan mengorientasikan kepala ke utara. Sementara itu, bagian-bagian tubuh lain terdapat di selatan dalam kondisi yang tidak beraturan. Menurut Widianto (2002) kondisi semacam itu menunjukkan adanya penguburan terlipat.

\section{Pecahan Tembikar}

Tembikar yang diteliti berasal dari tiga tahap ekskavasi, yaitu ekskavasi tahun 2000, 2001, dan 2002. Dari ketiga tahap ekskavasi itu dikumpulkan pecahanpecahan tembikar yang berasal dari beberapa kotak ekskavasi dan lapisan tanah tempat pecahan-pecahan tembikar itu ditemukan. Pecahan-pecahan tembikar ditemukan di 11 kotak di antara 14 kotak yang telah diekskavasi. Kotak-kotak yang mengandung temuan tembikar adalah H21, J6, J13, J20, K18, L17, L18, M15, N6, N9, dan N12. Sebelas kotak itu secara horizontal tersebar hamper ke seluruh pemukaan lantai gua. Sembilan diantara 11 kotak, yaitu kotak-kotak H21, J20, K18, L17, L18, M15, N6, N9, dan N12 terletak di dekat dinding gua bagian belakang, sedangkan kotak-kotak J6 dan J13 terletak di dekat mulut gua. Secara vertical pecahan-pecahan tembikar itu terletak antara spit (1) dan spit (7) atau terletak pada lapisan top soil dan awal lapisan tanah pertama. Pecahan tembikar di H21 ditemukan di spit (2) -(6), J6 di spit (1) - (5), J13 spit (2) - (5), J20 spit (2) - (6), K18 spit (1) - (3), L17 spit (2), L18 spit (2) - (4), M15 spit (1) - (2), 
N6 spit (1) - (7), dan N12 spit (1) - (4).

Pecahan tembikar pada setiap kotak jumlahnya berarivasi antara 118 buah hingga kurang dari 10 buah, Kotak-kotak yang mengandung temuan pecahan tembikar kurang dari 10 buah terdapat di kotak K18 dan L17, sementara itu kotak-kotak yang mengandung temuan pecahan tembikar paling banyak terdapat di kotak $\mathrm{H} 21$ berjumlah 152 buah dan kotak N12 berjumlah 118 buah. Jenis pecahan tembikar terdiri atas bagian tepian, leher, badan dan dasar. Pecahan bagian tepian, leher, dan dasar jumlahnya lebih sedikit dibanding dengan pecahan yang berasal dari bagian badan. Pecahan bagian badan $95,17 \%$ dari jumlah keseluruhan pecahan, tepian $3,72 \%$, leher $0,68 \%$, dan pecahan bagian dasar $0,42 \%$. Prosentase pecahan bagian tepian yang relatif kecil menupakan kunci dalam menentukan bentuk mula tembikar. Berdasarkan pecahan tepian itu dapat diidentifikasi dua bentuk mula tembikar, yaitu periuk dan mangkok. Jumlah periuk lebih banyak dibanding jumlah mangkok Pecahan bagian dasar pada umumnya berasal dari bentuk mangkok berdasar cekung dan beberapa terdapat mangkok berkaki lingkar.

Perbedaan-perbedaan tembikar lain yang terdapat di Situs Song Tritis adalah bahan pembuat, teknik pembuatan, kualitas pembakaran, dan ketebalan dinding. Bahan pembuat yang digunakan dalam pembuatan tembikar Song Tritis, paling tidak terdapat tiga kelompok bahan dasar, yaitu campuran tanah liat dan pasir berbutir sedang hingga kasar dan tanah liat bercampur pasir berbutir sangat halus. Teknik pembuatan terdiri atas tiga macam cara, yaitu menggunakan metode tangan tanpa menggunakan alat bantu lain, roda putar lambat, dan roda putar cepat. Tembikar yang dibuat dari bahan tanah liat bercampur pasir sedang merupakan tembikar produksi lokal, dibuat dengan menggunakan tangan dan roda putar lambat. Tembikar yang dihasilkan dengan menggunakan pembuatan dengan tangan tanpa alat bantu lain menghasilkan tembikar yang dinding-dindingnya tidak rata dan permukaan bagian luar dan dalam tidak rata, dan penampang tepian dan bagian badannya tidak simetris. Tembikar yang dibuat dengan roda putar lambat hasilnya lebih halus, tetapi di beberapa bagian tembikar itu terdapat ketebalan yang tidak rata. Tembikar yang dibuat dengan tangan tanpa bantu lain dan yang menggunakan roda putar lambat tampaknya merupakan produk gerabah lokal, temperatur pembakaran pada umumnya cukup tinggi. Bahan pembuat tembikar yang bahkan 
menggunakan cara pembuatan tersebut berupa tanah liat dicampur pasir berbutir sedang hingga kasar dengan temperatur pembakaran tinggi. Berdasarkan ukuran dindingnya, tembikar Tritis dapat dikelompokkan menjadi tiga bagian, yaitu tipis, sedang dan tebal. Tembikar yang berdinding tipis merupakan tembikar nonlokal bertemper sangat halus dan dibentuk dengan menggunakan teknik roda putar cepat dan dengan temperatur pembakaran cukup tinggi. Tembikar yang memiliki dinding berukuran sedang dan tebal merupakan tembikar lokal yang dibuat dengan teknik pembuatan dengan menggunakan tangan tanpa bantuan alat lain dan menggunakan roda putar lambat. Dinding tembikar berukuran tipis antara 2,5-3,5 mm sedangkan dinding yang berukuran sedang hingga tebal berukuran 7,5-11 $\mathrm{mm}$.

Di antara tembikar lokal mempunyai persamaan tipe dengan situs di dekat Tritis, sedangkan tembikar berkualitas bagus (halus) ditemukan persamaan tipenya di situs yang lebih jauh. Tembikar Tritis berkualitas lokal persamaannya ditemukan di Situs Gunungwingko(Bantul), suatu situs yang terletak limapuluh kilometer di sebelah barat Tritis. Tembikar Tritis yang memiliki persamaan dengan situs ini ialah mangkuk berdasar bulat dan mangkuk yang berkaki lingkar. Di Situs Gunungwingko, kedua jenis mangkok ini ditemukan pada lapisan budaya ketiga yang pertanggalan relatifnya berasal dari abad ke-10 hingga abad ke-14 M (Goenadi, 2001). Hasil analisis $\mathrm{C}_{14}$ pada lapisan budaya ketiga berasal dari 1000 tahun yang lampau atau sekitar abad ke-10 atau abad ke-11. Fase kehidupan itu rentang waktunya cukup panjang, sehingga tingkat akurasinya kurang tepat. Meskipun demikian, abad ke10 atau abad ke-11 termasuk dalam rentang waktu tersebut.

Jenis tembikar berkualitas bagus yang ditemukan di Situs Trowulan berasal dari bentuk mangkok dan periuk. Tembikar ini bukan tembikar lokal, melainkan tembikar yang berasal dari luar Indonesia. Tembikar jenis ini paling banyak ditemukan di Situs Trowulan, dan di Malaysia dikenal sebagai tembikar Majapahit. Kontek dengan pertanggalan situs menunjukkan bahwa tembikar Majapahit berasal dari abad ke-14 atau abad ke-15. Pertanggalan relatif dari kedua jenis temuan itu masih dapat dikelompokkan ke dalam pertanggalan absolut yang berasal dari lapisan tanah pertama Situs Song Tritirs. Dengan demikian Situs Song Tritis, berdasarkan bukti-bukti tersebut tetap digunakan sebagai lokasi permukiman dan 
bahkan masih berlangsung terus hingga abad ke-17. Jenis permukimannya belum diketahui secara jelas-lebih-lebih pada periode akhir sekitar abad ke-17-apakah permukiman menetap atau sementara.

\section{Beberapa Pendapat}

Data pertanggalan paling tua dari penelitian tahun 2002 adalah 8000 tahun yang lalu, berarti terletak pada lapisan tanah ketiga. Sementara itu di lapisan tanah ketiga bagian atas diperoleh pertanggalan 6000 tahun lampau, sehingga aktivitas permukiman di lapisan tanah ketiga cukup panjang. Selanjutnya pada lapisan tanah kedua terdapat data permukiman yang berasal dari 3000 tahun lampau, dan pada lapisan tanah pertama sekitar 1000 tahun lalu, dan akhimya pada lapisan top soil terdapat pertanggalan antara abad ke-10 hingga abad ke-17 M. Deretan pertanggalan tersebut menunjukkan aktivitas kehidupan yang berkelanjutan dalam suatu gua hunian.

Lingkungan di sekitar gua tampaknya relatif sama sepanjang kehidupan itu terutama keadaan flora dan fauna. Hal itu terbukti adanya tulang-tulang binatang seperti Macaca Sp dari lapisan tanah pertama hingga lapisan tanah top soil. Suatu kenyataan bahwa Macaca $S p$ sekarang tidak ditemukan lagi di lingkungan Song Tritis, meskipun beberapa penduduk sekitar memberi informasi bahwa keberadaannya masih dapat disaksikan meskipun sudah sangat jarang. Informasi itu membuktikan bahwa tingkat kepunahan Macaca Sp cukup tinggi, karena sejak ribuan tahun yang lalu telah dibantai dijadikan sumber protein hewani utama. Keadaan binatang itu lama kelamaan makin jarang dan tampaknya mencapai puncaknya pada kehidupan yang terjadi di lapisan tanah pertama. Lebih-lebih masa-masa terakhir kehidupan di Song Tritis, yaitu sekitar abad ke-17 M keadaan kehidupan Macaca $S p$ sudah jarang digunakan sebagai sumber protein hewani utama karena pada waktu itu telah terjadi peternaan hewan lain seperti ayam, kambing, dan sapi yang lebih memberikan kemudahan manfaat dalam kehidupan manusia. Keadaan flora di sekitar Song Tritis tidak banyak diketahui, karena jenis tumbuh-tumbuhan masa lampau belum banyak diketahui. Tentu saja banyak tumbuh-tumbuhan yang telah punah, tetapi sebagian masih dapat dilihat di sekitamya. Matapencaharian manusia gua belum dapat diketahui, tetapi masa 8000 tahun 
lampau adalah masa pengumpul makanan, sehingga belum melakukan kultivasi tanam-tanaman pangan seperti padi dan jagung. Pada waktu-waktu yang lebih muda yaitu pada kehidupan di lapisan tanah kedua, berdasarkan pertanggalan itu secara umum manusia telah mengenal pertanian. Tetapi, komunitas Song Tritis belum dapat diketahui matapencahariannya. Berdasarkan lingkungan di sekitarnya komunitas itu hidup dari mengumpul makanan. Baru pada tahap kehidupan di lapisan tanah pertama dan top soil mereka sudah melakukan cocok tanam, tetapi masih bermukim di dalam gua. Bahkan tampak sudah menjalin hubungan dengan komunitas di luar Tritis. Aktivitas itu dibuktikan dengan adanya tembikar yang persamaannya ditemukan di beberapa situs. Tidak diketahui bagaimana mereka berinteraksi dengan komunitas luar, tetapi jalur hubungan itu lewat darat, karena jalur laut tidak memungkinkan karena Samudera Hindia berombak sangat besar.

Dalam kehidupan mereka tampak telah mengenal kehidupan religi dengan ditemukan rangka manusia di lapisan tanah kedua bagian atas. Kepala rangka manusia itu tidak ditemukan, tetapi hanya ditemukan rahang bawah (mandibula) terletak di utara, sedang tulang belulang lainnya terdapat di selatan dalam kondisi yang tidak beraturan. Berdasar pengamatan di lapangan Hary Widianto (2002) menyimpulkan bahwa rangka tersebut dikubur dengan kepala di utara dengan sistem penguburan terlipat. Cara penguburan dengan cara apa pun pasti mempunyai maksud tertentu, lebih-lebih penguburan yang disertai dengan bekal kubur. Struktur kubur yang terbentuk pada suatu penguburan adalah hasil pemikiran orang yang masih hidup yang mempunyai konsep pemikiran tertentu. Bekal kubur misalnya, untuk memberi bekal pada si mati dalam perjalanan ke alam roh, demikian cara penguburan dan orientasi kepalanya.

Gambaran seperti itu telah banyak diuraikan oleh para ahli sebelumnya antara lain R.P. Soejono (1984) dan E.O. James (1962). Bekal kubur yang disertakan dalam penguburan dimaksudkan agar perjalanan si mati ke dunia roh dan kehidupan selanjutnya akan terjamin sebaik-baiknya (Soejono, 1984:204). Selanjutnya ditambahkan bahwa persembahan bekal kubur selain berupa makanan dan minuman, disertakan pula persembahan lain berupa oker, kerang, dan amulet yang menjadi bekal penting dalam perjalanan ke dunia berikutnya dan sangat berguna 
untuk memulai hidup baru (James, 1962: 117). Orientasi kepala ke arah mata angin tertentu memilik maksud tertentu pula antara lain menunjukkan asal nenek moyang (O'Shea, 1984), atau pemujaan tertentu misalnya gunung atau matahari.

Rangka manusia yang ditemukan di lapisan tanah kedua menunjukkan penguburan terlipat dengan kepala di utara. Konteksnya dengan temuan pecahan mangkok berkaki lingkar cukup penting. Orientasi keutara menggambarkan bahwa tempat tinggal nenek moyang mereka berada di utara, karena di utara tidak terdapat gunung. Orientasi ini mudah diperkirakan maksudnya, dan nenek moyang mereka tidak mungkin berasal dari selatan, karena terhalang oleh samudra yang sangat luas. Lokasi asal nenek moyang mereka yang terletak di utara belum dapat ditentukan lokasinya. Apabila dilihat dari Song Tritis memang asal nenek moyang mereka dari utara, tetapi sebelum mereka bermukim di utara dapat juga berasal dari timur atau barat kemudian baru menuju ke selatan.

- Sementara itu, mangkok berkaki lingkar diduga sebagai bekal kubur, karena mangkok jenis itu tidak digunakan sebagai perlengkapan sehari-hari. Konteks mangkok berkaki lingkar dengan penguburan yang contohnya diketahui di Situs Gunungwingko (Goenadi, 2001). Dengan demikian dapat diduga bahwa mangkok berkaki lingkar yang ditemukan di Situs Song Tritis memiliki fungsi sama dengan mangkok berbakaki lingkar yang ditemukan di Situs Gunungwingko.

Rangka manusia yang ditemukan pada lapisan tanah kedua tampaknya berumur lebih muda dari 3000 tahun atau berumur sekitar 2000 tahun lampau atau awal Masehi. Berdasarkan uraian sebelumnya, maka manusia Song Tritis pada sekitar 2000 taahun lampau telah mengenal religi. Orientasi kepala ke utara bukan suatu kebetulan, melainkan telah dipertimbangkan masak-masak sebelumnya. Manusia Song Tritis sudah memiliki konsep pemikiran tentang penguburan yang menjadi keyakinan mereka. Religi lain yang sudah diyakini ialah adanya keyakinan adanya kehidupan lain sesudah mati, yang dibuktikan oleh adanya wadah bekal kubur berupa mangkok berkaki. 


\section{Penutup}

Keberadaan gua-gua yang dijadikan permukiman berkelanjutan masa lampau di Indonesia jumlahnya tidak banyak. Oleh karenanya Song Tritis perlu didayagunakan untuk berbagai macam tujuan misalnya untuk pendidikan, kebanggaan daerah, dan tujuan ekonomi lain. Song Tritis perlu diangkat menjadi objek wisata daerah. Pemberdayaan Song Tritis sebagai objek wisata banyak faktor pendukungnya, antara lain lingkungannya seperti pemandangan indah, sarana jalan tidak banyak memerlukan biaya, dan kehidupan tradisional khususnya pertanian yang terdapat di sekitarnya dapat melengkapi keberadaan Song Tritis sebagai objek wisata. Objek wisata di Gunung Kidul sudah banyak, antara lain Pantai Baron yang dapat dikemas menjadi suatu paket wisata. Banyak manfaat yang diperoleh pemberdayaan Song Tritis sebagai objek wisata, antara lain kelestarian situs tetap terjaga dan dapat dijadikan objek pendidikan terutama sejarah kehidupan lokal yang pada akhirnya akan menambah rasa cinta pada daerah dan tanah air.

\section{DAFTAR PUSTAKA}

Goenadi Nitihaminoto. 2001. Situs Gunungwingko: Sebuah Rekonstruksi Kehidupan Masyarakat Akhir Perundagian. Disertasi. Program Pascasarjana, Uniersitas Gadjahmada, Yogyakarta.

James, E.O. 1962. Prehistoric Religion A Study in Prehistoric Archaeology. Barne \& Noble Ine., New York.

O'Shea, John M., Mortuary Variability : An Archaeological Investigation. Academic Press, London.

Soejono, R.P. (ed). 1984. Sejarah Nasional Indonesia I. Balai Pustaka, Jakarta.

Widianto, Harry dan Retno Handini. 2002. Penelitian Song Tritis: Eksistensi dan Posisinya dalam Kerangka Situs Hunian Gua Prasejarah. Laporan Penelitian Arkeologi. Departemen Pendidikan Nasional. Pusat Arkeologi, Balai Arkeologi Yogyakarta. 